\title{
Russian-Speaking Jewry Communal and Congregational Life Abroad: the Role of Language
}

\author{
Gregory Ser $^{1}$, Larissa Talalova ${ }^{2 *}$ \\ ${ }^{1}$ NNLS, 80 East End Road, London, N3 2SY 0208346 8560, UK \\ ${ }^{2}$ State University of Management, Russian Language Chair, 99, Ryazansky pr., Moscow, \\ Russian Federation
}

\begin{abstract}
The authors explore the Russian Jews diaspora which represents the viable mechanisms of real functioning in a host society. The article marks three criteria that help to be navigated among the options how the Russian Jewish immigration in the UK pans out in terms of: a) preserving the mother tongue, b) sticking to the home culture and c) whether the Russian Jews choose to adopt the host culture, whether they partly integrate into it or they fully assimilate.
\end{abstract}

\section{Introduction}

The new tendency towards the popularity of Russian as a foreign language abroad is determined by both social and economic factors. They, in their turn, reflect the pragmatic character of this sort of interest. The groups of potential learners are presented by:

1. a) adults who are eager to study Russian as a foreign language because of their professional activity (business, predominantly, it is the tourism and hospitality spheres); b) migrants who are searching the job places in the service sector (hotel and restaurant business) which requires active communicative skills; c) adults of different ages with high interest to the Russian language and culture.

2. a) students of linguistic departments who choose Russian as a second foreign language; b) students of non-linguistic departments who are striving to find their future work which is affiliated with the Russian structures or that one which necessitates the acquisition of the Russian language (the Russian culture discourse and the Russian mentality are included).

3. a) bilingual and multilingual children (especially in the international and interracial couples); b) children who are Russians ethnically but don't speak Russian.

\footnotetext{
* Corresponding author: talalova@gmail.com
} 


\subsection{Background}

\subsubsection{Objectives}

The specialists' ascending interest towards the reasons which tend the foreigner to start learning Russian as well as to the cohorts of learners themselves is valid. The latter while determining these reasons are very representative for our analysis. Exploring all these reasons necessitates the precise study of each one taken separately, thus we need some limitations. For example, while speaking on the point 1. c), i.e. on the adults of different ages who are interested in the Russian culture and language (culture-oriented learners) we may point out that their percentage is far from being significant and despite of the fact they are the only group who studies Russian without any pragmatic background, this cluster of learners is beyond our study. Thus, we will be centred on some groups we are interested in because consider them being practically epistemic. We will deal with the last group within our list, group 3, because these children together with their parents represent the viable mechanisms of real functioning in a host society (moreover, we make the group even more precise, we will speak on the Russian Jews diaspora). To see how it works is our objective.

\subsubsection{Methodology}

Methods of investigation are: the theoretical (analysis, synthesis, and generalization) and empirical (observation) ones. We used also the historical analysis for finding correlations with nowadays situation. A cause-and-effect analysis was also very productive for us.

\subsection{Regional component}

We will illustrate the means and patterns that the community of Russian Jews immigrants utilize in order to actualize themselves into a given host society. We will use the UK as a sample of the host society.

\section{Discussion}

To start off, we would like to put on the map three criteria that will hopefully navigate us here. The authors will attempt to show how the Russian Jewish immigration in the UK pans out in terms of: a) preserving the mother tongue, b) sticking to the home culture and c) whether the Russian Jews choose to adopt the host culture, whether they partly integrate into it or, rather, they fully assimilate.

Let us stop at the language first. It is a surface level fact that the Russian-speaking communities in the UK, both Jewish or else, choose to stick to Russian as their home language and the language to communicate with other fellow native Russian speakers, as opposed to English. It is enough to have a glance on the site of the RF Embassy in UK with its list of contacts of the Russian-speaking community associations [1].

The afore-mentioned fact has a cause-and-consequence relationship with series of Jewish-themed conferences called Limmud. Translated from Hebrew as 'to learn', Limmud originated in the UK in 1980 as a community-driven conference platform that would allow the Jews to study the Jewish holy texts and scriptures together for a few days in one remote place, the motto of it is formulated on its site: "Wherever you find yourself, Limmud will take you one step further on your Jewish journey." [2]. Limmud has since evolved into a $2-$ 3 thousand strong gathering that runs for up to a week and covers an extended cluster of themes with a Jewish interest. Looking at the upcoming events presented on the site we 
may read: "Regional and national Limmud events happen across the UK all year round, ranging from day events to our flagship week-long Limmud Festival." [2]. Since the end of November 2020 up to February 2021 at least three events are enumerated.

The English-speaking Limmud has become a truly global franchise and gained itself a fully Russian-speaking satellite called Limmud FSU (Former Soviet Union) which is aimed at including Russian-speaking Jews from the former Soviet republics in the larger movement. The first Limmud FSU took place in 2006 in Moscow and soon spread around the world in places where Russian-speaking Jews would be able to make up the scene, mostly Israel, US and Western Europe. The newly-realised popularity of the recent Limmud FSU events organised outside of Russian-speaking states has proven that Jewish immigrants from the former Soviet republics strongly prefer to use Russian at home and within the community, otherwise the perhaps more mainstream English-speaking counterpart would suffice. The latest Limmud FSU Europe has taken place in Vienna on March 3 2020, and the site article dedicated to this event has the subtitle "Austrian Minister for the EU Karoline Edtstadler: 'if Jewish life is under pressure - Europe is under pressure'." [3].

There are other two noteworthy trends concerning the subject of language. The first is such that Russian-speaking immigrants, Jewish or else, consciously choose to learn the host language to a degree high enough not only to work alongside with the locals but also to be able to socialise with them. The other trend is that the Russian speakers in the UK make a point of passing Russian to their children. A contrasting case of Italian migrants in the UK should come in handy here. There are an estimated number of 233,000 Italian-born residents in the UK with about 10 Italian nurseries and schools present in London. In turn, the estimated 70,000-strong Russian-speaking community can count on the same number of Russian nurseries and schools in London, just under 10. Consequently, Russian speakers are almost 4 times more likely to teach their children their mother tongue outside home than the Italians.

A similar trend is likely to be found within the Russian-speaking Jewish community with some slight variations as Jewish nurseries and schools in the UK are multiple (over 20 in London alone) and offer programs with a prevalent Hebrew component. Therefore, when the Russian-Jewish parents choose to send their child to a Hebrew school, Russian is naturally going to be less present in that child's education unless additional Russian classes were taught to them on an extra-curricular basis. More on that will be later.

Now let us talk about how the Russian-speaking Jews express and exercise their culture. It is fair to say, the Russian-Jewish culture is somewhat twofold. On one hand the Russian Jews are Russian, on the other, they are Jewish. To understand the dichotomy and the reasons of it, we will require adding the language into the equation again.

The first question we would probably need to ask ourselves here is whether a given culture relies on language and if so, whether that culture dies out in places where the language associated with it dies out. The gut instinct would tell us that there is a direct correlation, if there's a Russian community in Belfast that stops speaking Russian and adopts English as their home and intra-communal language, the chances are we will be talking about the end of the Russian culture in Belfast. Instead, they would consider themselves British and lose connection with the Russian culture forever. The same goes for descendants of Dutch, Polish, French, Spanish, etc. migrants in the UK.

But the Jewish culture is nested in a language to a much lesser degree. Since the Roman-Jewish wars between years 66 - 135 of common era until the year 1948 (Israel as a state appeared) Jews were dispersed around the world and, whether forcefully or willingly, had to learn and fully incorporate the languages of the hosting nations and/or develop new languages that would be rooted in the local languages with borrowings from the ancestral Hebrew or Aramaic, such as Yiddish in German and Slavic States and Ladino in Spain. 
That said, no matter how persistently the dominating languages invaded the Jewish communities in exile, we do not observe the Jewish identity in those places being fully erased as the result, even though the attempts have taken place. The most recent example of that would be the case of Yiddish in the $20^{\text {th }}$ century. Before the war Yiddish was a mother tongue to more than 60 percent of the world Jewry, and today only about 10 percent of Jews speak the language. Furthermore, only a third of the world Jewish population speaks Hebrew natively, mostly Israelis and Israeli expats, and yet the global Jewish identity capital appears to be untouched by these two phenomena.

Instead, Jewish culture as of today is celebrated in a plethora of languages, and the nonSemitic English and Russian are far from playing second fiddles.

It appears as if Jewish people elaborated a communal system and lifestyle that would allow them to survive despite the adversities and cases of ethno-linguistic cleansing because, according to Ron Wolfson, the community's mission is to allow people to fulfil obligations, which in its turn is intended to perfecting the human being and the world [4].

Some researches put Rabbinical Judaism as the leading gun in the arsenal. From the year $70 \mathrm{CE}$ and the Roman expulsion from the province of Judea that would begin the life in exile, the rabbis faced the task of adapting the principles and rituals of the faith to the new reality. During the times of the Temple and national land, the Jewish religious life had been centred on the temple sacrifices and was governed by the Oral law that lacked codification. In the scary new Temple-less world, two major projects were launched.

The first one was to replace the now impossible sacrifices with individual and communal prayer, and that's how the modern Jewish (and Christian) liturgy began to take form. The second project was to codify the Jewish law, which would eventually generate the emergence of the Babylonian Talmud between the $4^{\text {th }}$ and the $6^{\text {th }}$ centuries CE that would arguably become the standard Talmud as we know it. From then on, the Jewish life was built around the communities where people could: a) pray together, b) study Talmud together. Joseph B. Soloveitchik marks the unity as a basic principle, and he highlights the unity of Jewish people as members of a spiritual-religious entity tied through a unique Jewish way of life and tradition, a common past and a collective future [5].

It didn't matter where and when, as long as there was a sufficient group of observant and literate people (then men) plus an infrastructure as Jews were often considered aliens and led an insulated lifestyle. Fast forward to the $19^{\text {th }}$ century, with the rapid emergence of national states in Europe, Jews become citizens of the new states, which allowed them to study in universities side by side with the hosting people, which, in turn, would eventually result in secularisation of a sizeable part of the Jewish population and create a divide between religious and secular Jews, but that's quite another story.

With secularisation, praying together would either vanish or become a nod to the tradition, and however the habit to study together would persist, albeit with Talmud largely out of the picture for many. This pursuit of knowledge became a state of cognition which "... is beneficial for: 1) the individual $<\ldots>$; 2) the family $<\ldots>$; 3 ) the community." [6]. In other words, once launched by Rabbinical Judaism, learning together in any place possible as opposed to keeping ancient sacrificial rituals in a certain place would shape the Jewish life to these days, let us think the difference between a desktop computer with a dial up connection and a hard drive versus a tablet computer, 5G and a cloud data storage: "as the community is equipped with all the resources needed, it should provide support to its vulnerable members upon request and foster individual well-being materially, morally and intellectually full time." [7].

Conclusively, today it is a global Jewish community. Arnold M. Eisen (US) gives the stratification of it: "1) the local Jewish community; face-to-face community built on the basis of clear and present needs $<\ldots>$ and held together primarily by the cement of personal connection linking each person and his or her $<\ldots>$ neighbor; 2) global, it comprises the 
Jewish people as a whole; 3) the 'middle-range' level consists of local groups synagogues, cultural organizations, and regional authorities." [8]. Louis Jacobs (UK) chooses the same levels for his classification to be explained: "An individual may belong to a particular synagogue, to which he pays membership dues $\langle\ldots\rangle$, and the synagogue may be affiliated to a particular movement $\langle\ldots>$. Each individual Jew is, in turn, part of the wider Anglo-Jewish community $<\ldots>$. As a Jew, he is also a member of the Jewish people with duties and responsibilities to Jews everywhere." [9].

Though the famous American philosopher from the Harvard University Lenn E. Goodman marks that " $\ldots$ in the framework of the modern Jewish thought the powerful individualistic tendencies arise certain tensions between the individual/communal interests" [10], all in all it is a macro group (homogeneous or not) of people with a sense of togetherness and a pronounced emphasis on education, whether secular, religious or both, let us remember 3 thousand people coming to Limmud every year for a second.

Now, we come back to the Russian Jews. The Russian Jewish identity today, with its duality, is the mix of the trends presented above. What's unique about the Russian Jews is that through the $20^{\text {th }}$ century by now the Russian Jewry has remained predominantly secular, which was naturally caused by the Soviet policies that had kept religion marginalised for decades. This, among other policies, has made the Russian component in the Jewish identity more prevalent and somewhat similar to its French counterpart, where Jews have been conditioned to see themselves as French of Jewish background since the Napoleonic Civil Code of the French, and very different from the British Jews.

The latter group has not seen suppression of faith for at least 200 years and neither have any attempts to make British Jews more British taken place for the same period. As the result, the Jews of the United Kingdom have remained both quite religious and very involved in the local secular context, and again, the pattern launched by the rabbis was covered earlier. Jewish life in Britain is thriving: for roughly 250,000 Jews living in the UK, there are $30+$ major synagogues, $20+$ schools, 3 cultural centres and a developed network of Jewish-dedicated businesses in London alone. All of that becomes available to a Jewish expat from Russia which is home to just under 200,000 Jewish people who can yet rely on a much more modest infrastructure.

\subsection{Assimilation}

Finally, let us stop at the cultural assimilation, integration and adoption. The three phenomena can serve as degrees at which an immigrant accepts and is accepted into the host culture, with assimilation representing the highest level, adoption as the lowest, and integration being somewhere in-between. We've partly covered the assimilation already when examples of a given culture fading away with its language were presented. It might be adequate to the UK, the traditionally Christian-European cultures are likely to assimilate within a few generations of their expats.

\subsection{Adoption}

When it comes to adoption, the example of the Chinese migrants might give us a hand. Language-wise, for migrants from China the accent is strongly in favour of the mother tongue, at least as far as the first generation expats are involved. Moreover, there are several China towns across the UK, where street signage uses both English and variants of Chinese dialects, whereas, say Russian-speaking quarters do not manifest the same trait. The phenomena might serve as an indicator of home culture-oriented socialising choices amongst Chinese expats despite of the fact the Chinese immigration is a rich source of undisputed business and employment success stories on the UK scene. 


\subsection{Integration}

The Jewish immigration, in its turn, has shown traits of integration. Being fully incorporated into the fabric of the larger British society, British Jews have been sticking to the ancestral culture. We may add that the Jewish people have established a consistent presence in the UK more than a millennium ago, and it appears as if the cultural pendulum is unlikely to move towards either the assimilation or indeed the adoption extremes for the Jews in Britain any time soon.

\section{Conclusion}

The final question that we might face in the discussion is which way the Russian Jews will go. The short answer is 'it depends'. For some being Russian is more important than being Jewish. If that's the case, we will be likely to see assimilation taking place, however, at a slightly slower pace than say for the Italians. Those who consider themselves more Jewish than Russian will probably be more likely to join the mainstream UK Jewish trends, make a use of the resources the British Jewry has to offer and immerse into the British Jewry almost completely, again, arguably with the loss of the Russian language as well as the culture it carries.

\section{Acknowledgments}

This paper was financially supported by the Russian Foundation for Basic Research, grant No. 20-012-22046.

\section{References}

1. Contact details of Russian-speaking community associations in Great Britain / Embassy of the Russian Federation to the United Kingdom of Great Britain and the Northern Ireland. URL: https://www.rusemb.org.uk/orgnationals/ (Access: October 22 2020)

2. Limmud: Upcoming Events / Limmud. URL: https://limmud.org (Access: October 12 2020)

3. Limmud FSU Europe gathered 600 Russian-speaking Jews in Vienna / Limmud FSU. URL: https://www.limmudfsu.org/hp-newsagragation/limmud-fsu-europe (Access: September 16 2020)

4. R. Wolfson. Relational Judaism: Using the Power of Relationships to Transform the Jewish Community. Jewish Lights Publishing, Woodstock (2013)

5. J.B. Soloveitchik. The Lonely Man of Faith. NY: Penguin Random House (2006)

6. S.R. Hirsch. Collected Writings of Rabbi Samson Raphael Hirsch. 9, Feldheim Publishers, Nanuet, NY (1997)

7. L.A. Talalova, L.N. Talalova. Relationship between an individual and community, in Proceedings of the Middle-Term Conference RC04 ISA. Culture and Education: Social Transformations and Multicultural Communication, July 24-26, 2019, Moscow, RUDN (2019). URL: http://conference-ifl.rudn.ru/37-44/ (Access: October 24 2020)

8. A.M. Eisen. Taking Hold of Torah: Jewish Commitment and Community in America. Bloomington: Indiana University Press (1999) 
9. L. Jacobs. Religion and the Individual. A Jewish Perspective. Cambridge: Cambridge University Press (1992)

10. L.E. Goodman. The Individual and the Community in the Normative Traditions of Judaism. In: D.H. Frank (Ed.) Autonomy and Judaism: The Individual and Community in Jewish Philosophical Thought. Albany: State University of NY Press (1992) 